\title{
Insidensi dan Intensitas Serangan Virus dan Kaitannya dengan Produksi Cabai Merah Keriting yang Diaplikasi Berbagai Warna Mulsa
}

\author{
Titi Tricahyati ${ }^{*}$, Suparman ${ }^{2}$, dan Chandra Irsan ${ }^{2}$ \\ ${ }^{1}$ Mahasiswa Program Studi Ilmu Tanaman, Fakultas Pertanian, Universitas Sriwijaya \\ Jl. Padang Selasa No. 524, Bukit Besar, Palembang 30139, Sumatera Selatan, Indonesia. \\ ${ }^{2}$ Dosen Jurusan Hama Penyakit Tumbuhan, Fakultas Pertanian, Univeritas Sriwijaya \\ Jl. Raya Palembang-Prabumulih KM 32 Indralaya, Ogan Ilir 3066, Sumatera selatan \\ *Alamat korespondensi: titi.tricahyati@gmail.com
}

\begin{tabular}{|c|c|}
\hline INFO ARTIKEL & ABSTRACT/ABSTRAK \\
\hline Diterima: $\quad 10-06-2021$ & \\
\hline Direvisi: $\quad$ 23-11-2021 & Incidence and Intensity of Virus Attack and Its Relation to the Production \\
\hline Dipublikasi:23-01-2022 & of Curly Red Chili Applied with Various Colors of Mulch \\
\hline
\end{tabular}

Keywords:

Curly virus disease,

Plant disease,

Vector insect,

Yellow virus

disease

Kata Kunci:

Penyakit tanaman,

Penyakit virus kuning,

Penyakit virus

keriting, Serangga

vektor
Chili is a horticultural commodity that has a high economic value, but in the cultivation there are several obstacles from pests, one of which is viruses. The viruses that attack chilies are usually transmitted by vector insects. This study aimed to determine the response of vector insects attracted to mulch color treatments which might have impact on the disease incidence and intensity caused by the transmitted virus. The study was conducted using seven plastic mulch colors as treatments and repeated three times, and arranged in the randomized block design. The variables observed included the disease incidence and intensity caused by viruses, as well as weight and number of chili fruit. The results showed that the use of color mulches had no effect on the incidence of both yellow virus disease and leaf curl virus disease as well as on chili fruit weight and number. However, blue, yellow, red, and white color mulches produced higher disease intensities than black, brown, and green mulches.

Cabai merupakan komoditas hortikultura yang memiliki nilai ekonomis tinggi, namun dalam budidayanya terdapat beberapa kendala dari hama dan penyakit. Penyakit yang sering ditemui yaitu penyakit kuning dan penyakit keriting daun yang disebabkan virus. Virus yang menyerang cabai biasanya ditularkan serangga vektor. Penelitian ini bertujuan untuk mengetahui respon serangga vektor yang tertarik pada masing-masing perlakuan warna mulsa yang akan berdampak pada insidensi dan intensitas penyakit. Percobaan dilakukan menggunakan tujuh warna mulsa plastik dan diulang sebanyak tiga kali, dan menggunakan rancangan acak kelompok (RAK). Variabel yang diamati meliputi insidensi dan intensitas penyakit kuning dan penyakit keriting daun, serta bobot dan jumlah buah cabai. Hasil percobaan menunjukkan bahwa penggunaan mulsa warna tidak berpengaruh pada insidensi penyakit virus kuning maupun insidensi penyakit virus keriting serta pada bobot buah dan jumlah buah cabai. Namun warna mulsa biru, kuning, merah, dan putih menghasilkan intensitas penyakit virus kuning maupun virus keriting yang lebih tinggi dibandingkan dengan mulsa warna hitam, coklat, dan hijau. 


\section{PENDAHULUAN}

Cabai merupakan salah satu komoditas hortikultura yang banyak dibudidayakan (Adriani, Hamzah and Adi Prasetya, 2019). Dalam budidaya cabai terdapat beberapa patogen penting yang menyerang, seperti virus. Virus pada cabai dapat terbawa oleh serangga vektor seperti Bemisia tabaci, dan Aphis gossypii (Mari, Laghri, Mari, Shah, and Shahzadi, 2013). B. tabaci (Hemiptera: Aleyrodidae), merupakan hama yang menyerang cabai dari fase nimfa sampai dewasa, selain makan $B$. tabaci juga berpotensi sebagai penyebar virus dan menurunkan produksi cabai (Sani, Ibrahim, Siti, Sumaiyah, Johari, Syari, and Norsazilawati, 2020). Populasi B. tabaci dapat mencapai $81,48 \%$ dari keseluruhan artropoda yang ada pada pertanaman cabai (Ghosh, 2020). Kepadatan B. tabaci pada cabai juga dapat dipengaruhi ciri morfologi tertentu seperti tinggi dan kerapatan trikoma pada daun, ketebalan daun, dan warna daun (Al-aloosi, Al-anbaki and Kamil, 2020).

Cara pengendalian yang dapat dilakukan untuk menekan keberadaan serangga vektor antara lain pengendalian secara fisik (Horowitz, Antignus and Gerling, 2011). Penggunaan mulsa merupakan salah satu cara yang dapat menekan keberadaan serangga vektor (Carmona, Delserone, Campos, Almeida, Ozório, Cardona, Wright, and McMechan, 2021). Warna kunig-hijau, kuning dan oranye dapat menarik bagi kutu daun untuk datang. Pada pemeliharaan kutu daun, warna oranye dan kuning juga dapat menimbulkan respon pertumbuhan yang lebih tinggi pada kutu daun dibandingkan warna lain (Cartier, 1966). Preferensi warna telah dideskripsikan sebagai penentu spesifik seperti bunga yang disukai serangga atau inang yang disukai serangga dari berbagai kelompok (Van Der Kooi et al., 2021).

Keberadaan serangga hama pada penggunaan mulsa plastik hitam cenderung lebih sedikit jika dibandingkan dengan penggunaan mulsa jerami (Nasruddin et al., 2020). Penggunaan warna yang kontras akan menarik perhatian serangga vektor (Niemann, Menssen and Poehling, 2021). Beberapa warna memiliki efek yang dapat memengaruhi ketertarikan serangga secara relatif (Long, Flint and Lepper, 2011).

Sudah banyak diketahui bahwa aktivitas serangga sangat terpengaruh oleh warna dan cahaya, salah satunya warna kuning yang diketahui disukai serangga dan digunakan sebagai warna perangkap serangga (Melin et al., 2007). Jika serangga menyukai warna tertentu, sangat mungkin serangga juga tidak menyukai warna tertentu, dan jika warna yang tidak disukai atau kurang disukai tersebut digunakan sebagai warna mulsa maka dapat mencegah masuknya serangga ke pertanaman dan pada akhirnya akan menekan penyakit yang ditularkan oleh serangga vektor. Mengingat banyaknya penyakit cabai yang disebabkan oleh virus dan ditularkan oleh serangga vektor, maka penelitian ini bertujuan untuk menyelesaikan masalah tentang apakah warna mulsa tertentu dapat memengaruhi kehadiran serangga vektor di pertanaman cabai merah keriting, yang akhirnya dapat menekan serangan virus yang ditularkan serangga vektor.

\section{BAHAN DAN METODE}

\section{Tempat dan Waktu.}

Percobaan ini dilaksanakan di Rumah Kaca Jurusan Hama Penyakit Tumbuhan, Fakultas Pertanian, Universitas Sriwijaya, dan di Lahan Percobaan Jurusan Hama Penyakit Tumbuhan Fakultas Pertanian, Universitas Sriwijaya, Indralaya dari Juli- Desember 2019. Gejala penyakit virus kuning dan virus keriting diamati pada tanaman cabai yang terdapat pada satu lahan yang sama, dimana terdapat 21 tanaman cabai per petakan dengan jumlah keseluruhan 441 tanaman cabai yang diamati.

\section{Rancangan Penelitian}

Percobaan ini menggunakan Rancangan Acak Kelompok, dengan tujuh perlakuan warna mulsa, yaitu mulsa plastik warna kuning, merah, hitam, hijau, biru, coklat, dan putih dengan tiga kali ulangan. Analisis data menggunakan Analysis of Variance (ANOVA), apabila perlakuan berpengaruh nyata maka dilakukan uji lanjut menggunakan Uji Beda Nyata Jujur (BNJ) dengan taraf 5\%.

\section{Pengolahan Lahan}

Persiapan lahan dimulai dengan pembajakan lahan menggunakan traktor sebanyak dua kali. Lalu dilakukan pengukuran lahan dengan ukuran 14,1 m $\times 11,1 \mathrm{~m}$, selanjutnya dilakukan pembagian bedengan sebanyak 21 bedengan yang digunakan untuk pengamatan penyakit kuning dan penyakit keriting daun, dengan ukuran $1,5 \mathrm{~m} \times 3 \mathrm{~m}$ dengan jarak antar bedengan $60 \mathrm{~cm}$ dan $100 \mathrm{~cm}$. Pemupukan dilakukan satu minggu sebelum penanaman cabai, dengan 
menggunakan pupuk kandang kotoran ayam dengan takaran $7 \mathrm{~kg} /$ bedengan atau setara dengan satu karung pupuk kandang dengan berat $\pm 35 \mathrm{~kg}$ dibagi ke dalam 5 bedengan. Untuk pemupukan selanjutnya digunakan pupuk NPK, dengan dosis 5 $\mathrm{gr} /$ tanaman setiap satu bulan sekali sejak 7 hst (hari setelah tanam) hingga 91 hst.

\section{Penggunaan Mulsa}

Mulsa dipasang pada bedengan sesuai warna perlakuan dan dilubangi dengan ukuran diameter 10 $\mathrm{cm}$ dengan jarak $30 \mathrm{~cm}$. Pemasangan mulsa dilakukan satu minggu setelah pemupukan lahan.

\section{Inokulum}

Sumber inokulum yaitu tanaman cabai yang terserang penyakit virus kuning sebanyak 10 tanaman dan yang terserang penyakit virus keriting sebanyak 10 tanaman. Sumber inokulum tersebut dipindah-tanam ke dalam polybag $10 \mathrm{~kg}$. Kemudian tanaman sakit dibawa ke rumah bayang atau tempat yang berjauhan dengan bibit cabai yang belum diberi perlakuan. Saat tanaman cabai dipindahkan ke lahan, maka sumber inokulum juga dipindahkan ke lahan dengan jarak $\pm 1 \mathrm{~m}$ dari tanaman cabai. Pada tanaman inokulum terdapat serangga vektor, seperti Aphis gosypii, Bemissia tabaci, dan Empoasca sp. yang datang secara alami ke tanaman inokulum.

\section{Persiapan Tanaman}

Persiapan bibit dimulai dari penanaman benih di baki tanam, benih yang digunakan adalah cabai varietas Siramping C 199. Bibit cabai berdaun 3-5 helai berumur 28 hst dipindahkan ke polybag. Persiapan tanaman ini mengikuti metode yang dimodifikasi dari Maulana \& Maulida (2018). Penyiraman baik di baki maupun di polybag dilakukan dua kali dalam sehari, pada pagi dan sore hari. Penanaman di lahan dilakukan sore hari ketika matahari sudah tidak terik, dengan cara membuat lubang tanam sedalam 10-15 cm, kemudian bibit berumur 56 hst dipindahkan dari dalam polybag ke dalam lubang tanam yang sudah dibuat. Seluruhnya terdapat 441 tanaman cabai.

\section{Pemeliharaan}

Pemeliharaan cabai di lahan dilakukan dengan penyiraman dan penyiangan gulma. Penyiraman dilakukan dua kali sehari pada pagi dan sore hari. Penyiangan gulma dilakukan secara manual, setiap satu minggu sekali pada daerah pinggiran tanaman.

\section{Pengamatan.}

Pengamatan gejala penyakit dilakukan setiap satu minggu sekali di lahan pertanaman cabai sejak 56 hst hingga 91 hst, dengan mencatat dan menghitung insidensi dan intensitas penyakit. Insidensi penyakit dihitung berdasarkan jumlah tanaman yang terserang virus dalam satu bedengan pada masing-masing perlakuan. Intensitas serangan virus dihitung berdasarkan skor keparahan gejala yang nampak pada tanaman. Pengamatan produksi buah tanaman cabai dilakukan hanya pada tanaman yang terserang virus perbedengan, dengan menghitung jumlah buah dan menimbang bobot buah tanaman cabai yang sudah layak dipanen. Panen dilakukan sebanyak 4 kali pada umur tanaman 75 hst, 80 hst, 85 hst, dan 90 hst.

Insidensi tanaman terserang virus kuning dan virus keriting dihitung dengan rumus sebagai berikut:

Keterangan:

$$
P P=\frac{X}{N} \times 100 \%
$$

$\mathrm{PP}=$ Persentase insidensi tanaman terserang virus kuning atau virus keriting

$\mathrm{X}=$ Jumlah tanaman terserang virus kuning atau virus keriting

$\mathrm{N} \quad=$ Jumlah tanaman yang diamati

Intensitas penyakit virus kuning dan virus keriting (Abadi, 2003) dihitung dengan rumus sebagai berikut:

Keterangan :

$$
I P=\frac{\sum(n \times v)}{Z N} \times 100 \%
$$

IP = Persentase intensitas penyakit virus kuning atau virus keriting

$\mathrm{n} \quad=$ Jumlah tanaman pada setiap kategori gejala

$\mathrm{v}=$ Nilai skor dari setiap kategori

$\mathrm{Z} \quad=$ Nilai skor dari kategori tertinggi $(\mathrm{v}=5)$

$\mathrm{N}=$ Jumlah tanaman yang diamati

Tabel 1. Skor gejala penyakit virus kuning atau virus keriting

\begin{tabular}{cl}
\hline Skor & Proporsi Gejala Serangan Virus/ Tanaman \\
\hline 1 & Tidak ada gejala 0 \% \\
2 & Bergejala ringan $>1 \%-25 \%$ \\
3 & Bergejala sedang $>25 \%-50 \%$ \\
4 & Bergejala berat $>50 \%-75 \%$ \\
5 & Bergejala sangat berat atau puso $>75 \%-$ \\
& $100 \%$ \\
\hline
\end{tabular}




\section{HASIL DAN PEMBAHASAN}

\section{Penyakit Virus Kuning Cabai dan Penyakit Virus Keriting Cabai}

Cabai yang terserang virus kuning memiliki gejala awal berupa warna daun yang berubah menjadi kuning, perlahan dimulai dari bagian pucuk tanaman atau pada bagian jaringan daun muda (Septariani dkk., 2020). Kemudian akan meluas dan menyebabkan penebalan tulang daun tanaman cabai, dan hanya menyisakan daun tanaman bagian bawah yang sudah tua. Virus ini menyebabkan daun menjadi kecil dan kerdil karena proses fotosintesis yang terganggu dan daun tidak berwarna hijau sempurna atau merata. Penyebaran virus kuning dapat dibantu oleh serangga vektor seperti kutu kebul (B. tabacı) (Ariyanti, 2014). Sedangkan tanaman cabai yang terserang virus keriting menunjukkan gejala berupa daun yang mengkerut, kerdil, dan ukuran daun yang terus menyempit (Tuhumury \& Amanupunyo, 2018; Akhter et al., 2014). Dari hasil pengamatan didapati tanaman yang terserang virus keriting juga terserang oleh virus kuning.-Windarningsih dkk. (2018) menjelaskan bahwa gejala lanjut dari penyakit virus keriting berupa daun-daun muda yang mengecil, kemudian daun menjadi berwarna kuning, tanaman akan menjadi kerdil. Pada keadaan tanaman yang memiliki dua gejala secara bersamaan, maka tanaman akan dihitung sebagai tanaman yang terserang virus kuning dan dihitung juga sebagai tanaman yang terserang virus keriting. Skoring gejala serangan disesuaikan dengan proporsi bagian tanaman yang menunjukkan gejala penyakit virus kuning ataupun penyakit virus keriting yang ada pada satu tanaman.

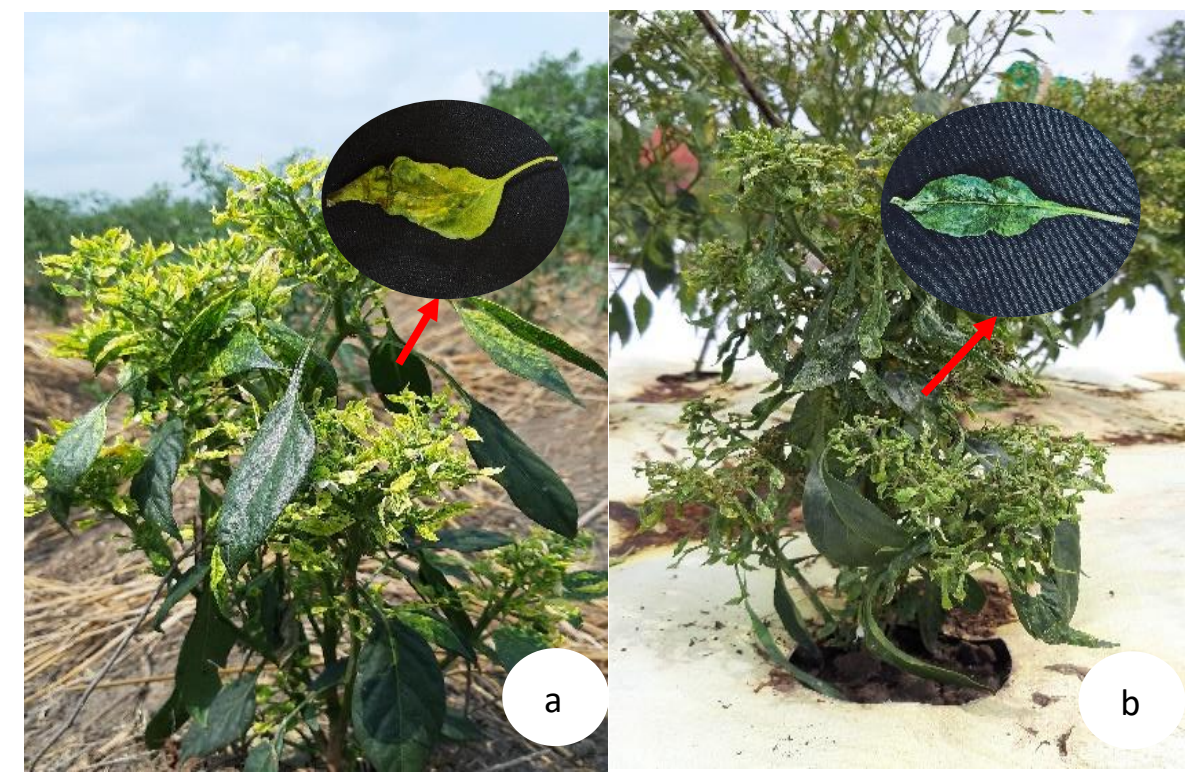

Gambar 1. Gejala serangan virus. a. virus kuning, b. virus keriting

\section{Insidensi Penyakit}

Dari hasil analisis data insidensi penyakit virus kuning dan virus keriting pada perlakuan berbagai warna mulsa (Tabel 2), pada pengamatan kelima dan keenam (84 dan 91 hst), dapat diketahui bahwa insidensi penyakit virus kuning yang paling tinggi mencapai $100 \%$ pada mulsa warna kuning, merah, dan hijau walaupun tidak berbeda nyata dengan insidensi pada mulsa warna lainnya. Insidensi penyakit virus keriting yang mencapai $100 \%$ terdapat pada perlakuan mulsa warna kuning, merah, hijau, dan putih (Tabel 2). Beberapa faktor yang memengaruhi hal tersebut antara lain faktor fisik, sebagai warna yang cukup diminati oleh serangga vektor karena tampilannya yang mencolok dan warna yang mudah ditangkap oleh serangga vektor. Hal tersebut didukung oleh pendapat Hasibuan (2017), yang menyatakan bahwa serangga cenderung paling tertarik pada warna kuning. Menurut penelitian Faradila dkk. (2019), warna kuning, putih, dan biru adalah warna yang menarik perhatian serangga. Farnier et al. (2014) juga menyatakan bahwa warna kuning, hijau, dan merah dapat menimbulkan ketertarikan serangga, dibandingkan warna gelap seperti abu-abu. Selain karena warna yang cukup mencolok tapi juga karena 
warna tersebut mudah ditangkap oleh sensor serangga vektor. Dari penelitian Holopainen \& Peltonen (2002) warna-warna yang cerah dapat berperan sebagai sinyal bagi kutu daun untuk menentukan tanaman yang baik untuk bereproduksi. Faktor pendukung lainnya adalah keberadaan $B$. tabaci, dan $A$. gossypii sebagai serangga vektor yang paling dominan meningkat akibat penelitian yang dilakukan pada musim panas (Marianah, 2020).

Tabel 2. Insidensi penyakit virus pada cabai yang diaplikasi berbagai warna mulsa

\begin{tabular}{lcccccc}
\hline \multirow{2}{*}{ Perlakuan } & \multicolumn{5}{c}{ Rerata Insidensi Penyakit (\%) Virus Kuning di Tanaman Cabai pada Pengamatan Ke-- } \\
\cline { 2 - 6 } & 1 & 2 & 3 & 4 & 5 & 6 \\
\hline Hitam & $10 \mathrm{a}$ & $51 \mathrm{a}$ & $79 \mathrm{a}$ & $79 \mathrm{a}$ & $86 \mathrm{a}$ & $86 \mathrm{a}$ \\
Coklat & $17 \mathrm{a}$ & $68 \mathrm{a}$ & $75 \mathrm{a}$ & $87 \mathrm{a}$ & $87 \mathrm{a}$ & $87 \mathrm{a}$ \\
Biru & $54 \mathrm{~b}$ & $84 \mathrm{a}$ & $89 \mathrm{a}$ & $98 \mathrm{~b}$ & $98 \mathrm{a}$ & $98 \mathrm{a}$ \\
Kuning & $52 \mathrm{~b}$ & $89 \mathrm{a}$ & $100 \mathrm{a}$ & $100 \mathrm{~b}$ & $100 \mathrm{a}$ & $100 \mathrm{a}$ \\
Merah & $41 \mathrm{~b}$ & $83 \mathrm{a}$ & $100 \mathrm{a}$ & $100 \mathrm{~b}$ & $100 \mathrm{a}$ & $100 \mathrm{a}$ \\
Hijau & $51 \mathrm{~b}$ & $86 \mathrm{a}$ & $70 \mathrm{a}$ & $100 \mathrm{~b}$ & $100 \mathrm{a}$ & $100 \mathrm{a}$ \\
Putih & $60 \mathrm{~b}$ & $59 \mathrm{a}$ & $89 \mathrm{a}$ & $98 \mathrm{~b}$ & $98 \mathrm{a}$ & $98 \mathrm{a}$ \\
\hline \multirow{2}{*}{ Perlakuan } & Rerata Insidensi Penyakit $\%)$ Virus Keriting di Tanaman Cabai pada Pengamatan Ke- \\
\cline { 2 - 6 } & 1 & 2 & 3 & 4 & 5 & 6 \\
\hline Hitam & $15 \mathrm{a}$ & $58 \mathrm{a}$ & $80 \mathrm{a}$ & $80 \mathrm{a}$ & $85 \mathrm{a}$ & $85 \mathrm{a}$ \\
Coklat & $19 \mathrm{a}$ & $68 \mathrm{a}$ & $84 \mathrm{a}$ & $87 \mathrm{a}$ & $87 \mathrm{a}$ & $87 \mathrm{a}$ \\
Biru & $57 \mathrm{~b}$ & $84 \mathrm{a}$ & $84 \mathrm{a}$ & $98 \mathrm{~b}$ & $98 \mathrm{a}$ & $98 \mathrm{a}$ \\
Kuning & $55 \mathrm{~b}$ & $90 \mathrm{~b}$ & $100 \mathrm{~b}$ & $100 \mathrm{~b}$ & $100 \mathrm{a}$ & $100 \mathrm{a}$ \\
Merah & $41 \mathrm{~b}$ & $84 \mathrm{a}$ & $100 \mathrm{~b}$ & $100 \mathrm{~b}$ & $100 \mathrm{a}$ & $100 \mathrm{a}$ \\
Hijau & $49 \mathrm{~b}$ & $85 \mathrm{a}$ & $100 \mathrm{~b}$ & $100 \mathrm{~b}$ & $100 \mathrm{a}$ & $100 \mathrm{a}$ \\
Putih & $66 \mathrm{c}$ & $85 \mathrm{a}$ & $96 \mathrm{a}$ & $98 \mathrm{~b}$ & $100 \mathrm{a}$ & $100 \mathrm{a}$ \\
\hline
\end{tabular}

Keterangan: Angka-angka yang diikuti huruf yang sama pada kolom yang sama berbeda tidak nyata pada taraf uji BNJ 5\%.

\section{Intensitas Penyakit}

Intensitas penyakit dihitung dari data skor gejala kerusakan pada seluruh tanaman cabai yang terserang virus. Dari hasil analisis data, serangan virus kuning pada tanaman cabai dengan intensitas tertinggi terdapat pada pengamatan keenam (91 hst), yaitu pada perlakuan mulsa dengan warna kuning sebesar 52,54\% namun tidak berbeda dengan perlakuan mulsa warna biru, merah dan putih (Tabel 3). Intensitas penyakit keriting pada tanaman cabai yang paling tinggi juga terdapat pada pengamatan keenam, yaitu penggunaan mulsa warna kuning sebesar 57,58\% dan tidak berbeda pula dengan perlakuan mulsa warna biru, merah dan putih (Tabel 3).

Warna kuning telah digunakan sebagai warna perangkap untuk beberapa serangga, seperti pada penelitian Farias-Larios \& Orozco-Santos (1997) dan Žanić et al. (2009) yang menggunakan warna kuning sebagai perangkap kutu daun pada tanaman semangka. Kutu daun dapat dapat menangkap gelombang cahaya yang lebih besar dari $500 \mathrm{~nm}$ yang terdapat pada warna hijau, kuning dan oranye, dan warna yang ditangkap secara maksimum tersebut adalah warna kuning (Kennedy et al., 1961). Pada percobaan ini penyakit virus kuning dan virus keriting terus berkembang dan meningkat saat memasuki fase tanaman berbunga, pada fase tersebut juga dijumpai peningkatan jumlah serangga vektor pada tanaman cabai.

Menurut Vivaldy dkk. (2017), populasi serangga meningkat sejalan dengan umur tanaman yang bertambah, tanaman cabai yang sudah terserang virus akan memberikan kesempatan lebih banyak bagi serangga vektor untuk menularkan virus pada tanaman cabai lainnya. Menurut Marianah (2020) intensitas serangan penyakit juga dipengaruhi oleh faktor lingkungan, umur tanaman, dan serangga vektor yang ada. Pada percobaan ini, intensitas penyakit juga meningkat karena hampir seluruh tanaman cabai sudah terserang virus. 
Tabel 3. Intensitas penyakit virus pada cabai yang diaplikasi berbagai warna mulsa.

\begin{tabular}{lcccccc}
\hline \multirow{2}{*}{ Perlakuan } & \multicolumn{6}{c}{ Rerata Intensitas Penyakit (\%) Virus Kuning di Tanaman Cabai pada Pengamatan Ke- } \\
\cline { 2 - 7 } & 1 & 2 & 3 & 4 & 5 & 6 \\
\hline Hitam & $1,78 \mathrm{a}$ & $7,74 \mathrm{a}$ & $17,68 \mathrm{a}$ & $20,01 \mathrm{a}$ & $23,61 \mathrm{a}$ & $26,96 \mathrm{a}$ \\
Coklat & $4,28 \mathrm{a}$ & $12,00 \mathrm{a}$ & $16,43 \mathrm{a}$ & $21,50 \mathrm{a}$ & $25,27 \mathrm{a}$ & $28,12 \mathrm{a}$ \\
Biru & $1,96 \mathrm{~b}$ & $20,35 \mathrm{~b}$ & $32,45 \mathrm{a}$ & $37,28 \mathrm{~b}$ & $41,21 \mathrm{~b}$ & $44,53 \mathrm{~b}$ \\
Kuning & $14,13 \mathrm{~b}$ & $22,10 \mathrm{~b}$ & $41,06 \mathrm{~b}$ & $44,80 \mathrm{~b}$ & $48,96 \mathrm{~b}$ & $52,54 \mathrm{~b}$ \\
Merah & $9,47 \mathrm{a}$ & $17,15 \mathrm{a}$ & $40,78 \mathrm{~b}$ & $44,59 \mathrm{~b}$ & $47,25 \mathrm{~b}$ & $50,54 \mathrm{~b}$ \\
Hijau & $12,26 \mathrm{a}$ & $19,47 \mathrm{~b}$ & $21,30 \mathrm{a}$ & $27,99 \mathrm{a}$ & $32,84 \mathrm{a}$ & $36,47 \mathrm{a}$ \\
Putih & $16,94 \mathrm{~b}$ & $22,98 \mathrm{~b}$ & $34,12 \mathrm{~b}$ & $38,67 \mathrm{~b}$ & $42,00 \mathrm{~b}$ & $44,87 \mathrm{~b}$ \\
\hline \multirow{2}{*}{ Perlakuan } & Rerata Intensitas Penyakit (\%) Virus Keriting di Tanaman Cabai pada Pengamatan Ke- \\
\cline { 2 - 7 } & 1 & 2 & 3 & 4 & 5 & 6 \\
\hline Hitam & $3,12 \mathrm{a}$ & $9,20 \mathrm{a}$ & $17,94 \mathrm{a}$ & $23,35 \mathrm{a}$ & $25,49 \mathrm{a}$ & $29,47 \mathrm{a}$ \\
Coklat & $4,78 \mathrm{a}$ & $12,00 \mathrm{a}$ & $19,83 \mathrm{a}$ & $23,93 \mathrm{a}$ & $29,25 \mathrm{a}$ & $33,14 \mathrm{a}$ \\
Biru & $14,10 \mathrm{~b}$ & $20,35 \mathrm{~b}$ & $25,24 \mathrm{~b}$ & $38,89 \mathrm{~b}$ & $43,84 \mathrm{~b}$ & $47,80 \mathrm{~b}$ \\
Kuning & $13,84 \mathrm{~b}$ & $22,84 \mathrm{~b}$ & $38,44 \mathrm{bc}$ & $47,89 \mathrm{~b}$ & $53,86 \mathrm{~b}$ & $57,58 \mathrm{~b}$ \\
Merah & $9,23 \mathrm{a}$ & $16,49 \mathrm{a}$ & $42,35 \mathrm{a}$ & $45,99 \mathrm{~b}$ & $49,55 \mathrm{~b}$ & $52,91 \mathrm{~b}$ \\
Hijau & $11,87 \mathrm{a}$ & $19,47 \mathrm{a}$ & $27,21 \mathrm{a}$ & $32,10 \mathrm{a}$ & $36,30 \mathrm{a}$ & $40,45 \mathrm{a}$ \\
Putih & $17,38 \mathrm{~b}$ & $23,08 \mathrm{~b}$ & $33,65 \mathrm{c}$ & $41,07 \mathrm{~b}$ & $45,03 \mathrm{~b}$ & $48,64 \mathrm{~b}$ \\
\hline
\end{tabular}

Keterangan: Angka-angka yang diikuti huruf yang sama pada kolom yang sama berbeda tidak nyata pada taraf uji BNJ 5\%.

\section{Produksi Cabai}

Dari hasil analisis data diketahui rerata total bobot buah (hasil empat kali panen) paling tinggi terdapat pada perlakuan mulsa warna putih, sebesar $15,0 \mathrm{~g} /$ tanaman. Rerata jumlah buah hasil empat kali panen paling tinggi terdapat pada perlakuan mulsa warna putih pula, sebesar 15,0 buah/tanaman. Rerata bobot buah paling rendah terdapat pada perlakuan mulsa warna biru, sebesar 6,9 g/tanaman. Rerata jumlah buah paling rendah terdapat pada perlakuan mulsa warna biru, sebesar 7,7 buah/tanaman. Dari empat kali panen cabai diketahui rerata bobot buah paling rendah terdapat pada perlakuan mulsa warna biru pada panen keempat, sebesar $1,1 \mathrm{~g} /$ tanaman. Rerata bobot buah paling tinggi terdapat pada perlakuan mulsa warna putih pada panen kedua sebesar 5,8 g/ tanaman. Rerata jumlah buah paling rendah terdapat pada perlakuan mulsa warna biru pada panen pertama, sebesar 1,4 buah/ tanaman. Rerata jumlah buah paling banyak pada perlakuan mulsa warna putih pada panen kedua sebesar 5,5 buah/ tanaman (Tabel 4).

Pada Tabel 3, perlakuan mulsa warna hitam, coklat dan hijau menyebabkan intensitas penyakit virus kuning maupun virus keriting yang paling rendah, namun pada rerata bobot buah dan jumlah buah, hasil yang diperoleh cenderung lebih rendah daripada perlakuan dengan intensitas penyakit virus kuning dan virus keriting yang paling tinggi, yaitu pada perlakuan mulsa warna kuning. Rendahnya angka produksi cabai pada perlakuan mulsa warna hitam tersebut diduga disebabkan karena banyaknya buah yang gugur dengan kondisi buah yang menghitam dan jaringan buah menjadi lunak sehingga tidak layak untuk dipanen. Gejala kerusakan ini dominan hanya didapati pada aplikasi mulsa warna hitam, sedangkan pada aplikasi mulsa warna lainnya gejala kerusakan serupa hanya ditemukan pada beberapa buah. Dari gejala yang diamati diduga kerusakan ini disebabkan oleh jamur patogen. Dari hasil penelitiannya, Ardhona et al. (2013), menyatakan bahwa tanaman cabai yang diaplikasi mulsa warna hitam juga menghasilkan buah gugur lebih banyak akibat penyakit. Menurut Orobiyi et al. (2013) keberadaan serangga hama, serangan virus, dan antraknosa pada cabai dapat menyebabkan gugurnya daun, bunga, dan buah lebih awal.

Menurut Syamsiah (2007) produksi tertinggi varietas Siramping C 199 dapat mencapai berat buah 820-870 g/ tanaman, dengan berat perbuah mencapai 4-5 g. Jika dibandingkan dengan hasil panen penelitian ini yang hanya mencapai 5,8 $\mathrm{g} /$ tanaman dan total tertinggi bobot buah dari empat kali panen 15,0 g/tanaman, maka bobot buah pada penelitian ini sangat rendah. Rendahnya produksi cabai diduga dipengaruhi oleh tanaman cabai yang sudah terserang virus, sehingga menyebabkan 
tanaman cabai tersebut tidak dapat berproduksi secara optimal. Pada intensitas serangan virus keriting yang mencapai lebih dari $75 \%$, daun tanaman cabai akan berukuran lebih kecil, pertumbuhan akan terhambat dan bunga pada tanaman lebih kecil dibandingkan pada keadaan normal, sehingga menghasilkan buah yang kerdil
(González-Pérez et al., 2011). Dari hasil penelitian Subekti dkk. (2006) infeksi virus menyebabkan terganggunya sistem metabolisme tanaman, akibatnya tanaman kekurangan bahan baku untuk melakukan aktifitas pertumbuhan baik vegetatif maupun generatif secara normal.

Tabel 4. Bobot buah dan jumlah buah yang diaplikasi berbagai warna mulsa.

\begin{tabular}{|c|c|c|c|c|c|c|c|c|c|c|}
\hline \multirow[t]{2}{*}{ Perlakuan } & \multicolumn{4}{|c|}{$\begin{array}{l}\text { Rerata Bobot Buah (g/ } \\
\text { tanaman) Panen ke- }\end{array}$} & \multirow{2}{*}{$\begin{array}{l}\text { Total } 4 \text { kali } \\
\text { panen }\end{array}$} & \multicolumn{4}{|c|}{$\begin{array}{l}\text { Rerata Jumlah Buah } \\
\text { Pertanaman Panen ke- }\end{array}$} & \multirow{2}{*}{$\begin{array}{c}\text { Total } 4 \text { kali } \\
\text { panen }\end{array}$} \\
\hline & P1 & P2 & P3 & $\mathrm{P} 4$ & & P1 & P2 & P3 & $\mathrm{P} 4$ & \\
\hline Hitam & 2,0 & 2,3 & 3,4 & 1,9 & 9,6 & 2,0 & 2,0 & 2,2 & 1,8 & 8,0 \\
\hline Coklat & 2,5 & 3,6 & 2,2 & 2,5 & 10,8 & 2,6 & 3,6 & 2,1 & 2,4 & 10,7 \\
\hline Biru & 1,4 & 1,8 & 2,6 & 1,1 & 6,9 & 1,4 & 1,8 & 2,7 & 1,8 & 7,7 \\
\hline Kuning & 3,2 & 4,8 & 3 & 1,4 & 12,4 & 3,1 & 5,3 & 3,6 & 1,9 & 13,9 \\
\hline Merah & 3,2 & 2,8 & 2,7 & 1,2 & 9,9 & 3,5 & 3,7 & 2,8 & 1,6 & 11,6 \\
\hline Hijau & 1,9 & 5 & 3,2 & 3,5 & 13,6 & 1,9 & 3,9 & 3,3 & 4,1 & 13,2 \\
\hline Putih & 4,2 & 5,8 & 3,3 & 1,7 & 15,0 & 4,3 & 5,5 & 3,3 & 1,9 & 15,0 \\
\hline
\end{tabular}

Keterangan: $\mathrm{P}=$ Panen, $\mathrm{P} 1=$ Panen ke-1, $\mathrm{P} 2=\mathrm{Panen}$ ke-2, P3= Panen ke-3, P4= Panen ke-4

\section{SIMPULAN}

Perlakuan warna mulsa tidak berpengaruh terhadap insidensi penyakit virus kuning maupun penyakit virus keriting. Insidensi penyakit virus kuning paling tinggi terdapat pada perlakuan warna mulsa kuning, merah, dan hijau dengan angka $100 \%$, sedangkan insidensi penyakit virus keriting yang mencapai $100 \%$ terdapat pada perlakuan mulsa warna kuning, merah, hijau, dan putih pada 91 hst. Intensitas penyakit virus kuning dan virus keriting paling tinggi terdapat pada perlakuan mulsa warna kuning, yaitu sebesar $52,54 \%$ pada penyakit virus kuning, dan $57,58 \%$ pada penyakit virus keriting, walaupun secara statistik tidak berbeda dengan intensitas pada perlakuan mulsa warna biru, merah, dan putih. Total bobot buah paling tinggi dan total jumlah buah paling tinggi terdapat pada perlakuan mulsa warna putih.

\section{UCAPAN TERIMA KASIH}

Penulis mengucapkan terimakasih kepada Dr.Ir. Suparman SHK dan Dr. Ir. Chandra Irsan, MSi. selaku pembimbing atas perhatiannya telah memberikan arahan dari mulai perencanaan, pelaksanaan, pendanaan, analisis data penelitian hingga akhir penyusunan dan penulisan artikel.

\section{DAFTAR PUSTAKA}

Abadi, AL. 2003. Ilmu Penyakit Tumbuhan 3. Bayu Media. Malang. $145 \mathrm{hlm}$

Adriani, D, M Hamzah, and MA Prasetya. 2019. The estimation of economic appearance and profitability function of drip irrigation in tidal lands (a case of chili farming). Sriwijaya Journal of Environment. 4(3): 138-145. doi: 10.22135/sje.2019.4.3.138-145.

Akhter, A, SAkhtar, M Saeed, and S Mansoor. 2014. Chili leaf curl betasatellite enhances symptoms induced by tomato leaf curl new Delhi virus, a bipartite begomovirus. International Journal of Agriculture and Biology. 16(6): 1225-1228.

Al-aloosi, ANS, HAM Al-anbaki, and SH Kamil. 2020. Host plant resistance, chili pepper to whitefly, Bemisia tabaci (Gennadius) (Hemiptera: Aleyrodidae) in field. International Journal of Agricultural and Statistics Sciences. 16(1): 103-106.

Ardhona, S, K Hendarto, A Karyanto, and YC Ginting. 2013. Pengaruh pemberian dua jenis mulsa dan tanpa mulsa terhadap karakteristik pertumbuhan dan produksi tanaman cabai merah (Capsicum annum L.). J. Agrotek Tropika. 1(2): 153-158.

Ariyanti, NA. 2014. Mekanisme infeksi virus kuning 
cabai (Pepper Yellow Leaf Curl Virus) dan pengaruhnya terhadap proses fisiologi tanaman cabai. In Seminar Nasional IX Pendidikan Biologi FKIP UNS. Surakarta : FKIP Univ. Sebelas Maret, 07 Juli 2012, pp. 682-686.

Carmona, GI, LM Delserone, JND Campos, TF Almeida, DVB Ozório, JDB Cardona, R Wright, and AJ McMechan. 2021. Does cover crop management affect arthropods in the subsequent corn and soybean crops in the United States? A systematic review. Annals of the Entomological Society of America. XX(X):1-12. doi: 10.1093/aesa/saaa049.

Cartier, JJ. 1966. Aphid responses to colors in artificial rearings. Bulletin of the Entomological Society of America. 12(4): 378-380. doi: 10.1093/besa/12.4.378.

Faradila, A, N Nukmal, dan G Dania. 2019. Keberadaan serangga malam berdasarkan efek warna lampu pada light trap di Kebun Raya Liwa. Jurnal Agroteknologi. 1(1): 1-7.

Farias-Larios, J, and M Orozco-Santos. 1997. Effect of polyethylene mulch colour on aphid populations, soil temperature, fruit quality, and yield of watermelon under tropical conditions. New Zealand Journal of Crop and Horticultural Science. 25(4): 369-374. doi: 10.1080/01140671.1997.9514028.

Farnier, K, AG Dyer, and MJ Steinbauer. 2014. Related but not alike: Not all Hemiptera are attracted to yellow', Frontiers in Ecology and Evolution. 2: 1-12. doi: 10.3389/fevo.2014.00067.

Ghosh, SK. 2020. Environmentally sound approach for management of tomato whitefly (Bemisia tabaci Genn.). Journal of Entomology and Zoology Studies. 8(6): 814-818.

González-Pérez, JL, MC Espino-Gudiño, I TorresPacheco, RG Guevara-González, G HerreraRuiz, and V Rodríguez-Hernández. 2011. Quantification of virus syndrome in chili peppers. African Journal of Biotechnology. 10(27): 5236-5250. doi: 10.4314/ajb.v10i27.

Hasibuan, S. 2017. Efektivitas perangkap warna dengan sistem pemagaran pada serangga hama tanaman. Seminar Nasional Multidisiplin Ilmua. doi: 10.31227/osf.io/e7xfg.

Holopainen, JK, and P Peltonen. 2002. Bright autumn colours of deciduous trees attract aphids: Nutrient retranslocation hypothesis.
Oikos. 99(1): 184-188. doi: 10.1034/j.16000706.2002.990119.x.

Horowitz, AR, Y Antignus, and D Gerling. 2011. The whitefly, Bemisia tabaci (Homoptera: Aleyrodidae) interaction with geminivirusinfected host plants. in MO Thompson (ed). The Whitefly, Bemisia tabaci (Homoptera: Aleyrodidae) Interaction with GeminivirusInfected Host Plants. 293-322 pp. doi: 10.1007/978-94-007-1524-0.

Kennedy, JS, CO Booth, and WWJS Kersha. 1961. Host finding by aphids in the field: III. Visual attraction', Annals of Applied Biology. 49(1): 1-21. doi: 10.1111/j.17447348.1961.tb03587.x.

Van Der Kooi, CJ, DG Stavenga, K Arikawa, G Beluši ${ }^{\vee}$, and A Kelber. 2021. Evolution of insect color vision: from spectral sensitivity to visual ecology. Annual Review of Entomology. 66: 435-461. doi: 10.1146/annurev-ento-061720-071644.

Long, CV, JA Flint, and PA Lepper. 2011. Insect attraction to wind turbines: Does colour play a role?. European Journal of Wildlife Research. 57(2): 323-331. doi: 10.1007/s10344-010-0432-7.

Mari, JM, RB Laghri, MA Shah, and AK Shahzadi. 2013. Eco friendly pest management of chili crop. Journal of Agricultural Technology. 9(7): 1981-1992.

Marianah, L. 2020. Serangga vektor dan intensitas penyakit virus pada tanaman cabai merah insect vector and virus disease intensity on red chili plants. AgriHumanis: Journal of Agriculture and Human Resource Development Studies. 1(2): 127-134.

Marveldani, E Maulana, dan D Maulida. 2018. Evaluasi daya hasil lima varietas cabai ( Capsicum annuum L .) dengan penggunaan mulsa plastik dan paranet saat transplanting. in Prosiding Seminar Nasional Pengembangan Teknologi Pertanian. Politeknik Negeri Lampung 08 Oktober 2018, pp. 259-265.

Melin, AD, LM Fedigan, C Hiramatsu, CL Sendall, and SI Kawamura. 2007. Effects of colour vision phenotype on insect capture by a freeranging population of white-faced capuchins, Cebus capucinus. Animal Behaviour. 73(1): 205-214. doi: 10.1016/j.anbehav.2006.07.003.

Nasruddin, A, N Agus, A Saubil, J Jumardi, B Rasyid, A Siriniang, A Dirham, Nasruddin, 
F Firdaus, and AE Said. 2020. Effects of mulch type, plant cultivar, and insecticide use on sweet potato whitefly population in chili pepper. Scientifica. 2020: 1-7. doi: 10.1155/2020/6428426.

Niemann, JU, M Menssen, and HM Poehling. 2021. Manipulation of landing behaviour of two whitefly species by reflective foils. Journal of Plant Diseases and Protection. 128(1): 97-108. doi: 10.1007/s41348-020-00394-y.

Orobiyi, A, A Dansi, P Assogba, LY Loko, M Dansi, R Vodouhe, A Akouegninou, and A Sanni. 2013. Chili (Capsicum annuum L.) in Southern Benin: production constraints, varietal diversity, preference criteria and participatory evaluation. International Research Journal of Agricultural Science and Soil Science. 3: 107-120.

Sani, I, SI Ismail, S Abdullah, S Jamian, and N Saad. 2020. A review of the biology and control of whitefly, Bemisia tabaci (Hemiptera: Aleyrodidae), with special reference to biological control using entomopathogenic fungi. MDPI. 11(619): 1-18.

Septariani, DN, Hadiwiyono, P Harsono, \& M Mawar. 2020. Pemanfaatan minyak serai sebagai bahan aktif nanovirusida untuk pengendalian penyakit kuning pada cabai. PRIMA: Journal of Community Empowering and Services. 4(2): 51. doi: 10.20961/prima.v4i2.39797.
Subekti, DWI, SH Hidayat, E Nurhayati, \& S Sujiprihati. 2006. Infeksi Cucumber Mosaic Virus dan Chili Veinal Mottle Virus terhadap pertumbuhan dan hasil tanaman cabai. HAYATI Journal of Biosciences. 13(2): 53-57. doi: 10.1016/S1978-3019(16)30381-3.

Syamsiah, S. Lampiran Keputusan Menteri Pertanian Nomor : 395/Kpts/SR.120/7/2007 Tanggal : 10 Juli 2007 tentang Deskripsi Cabai Keriting Varietas Siramping C 199

Tuhumury, GN, \& HR Amanupunyo. 2018. Kerusakan tanaman cabai akibat penyakit virus di Desa Waimital Kecamatan Kairatu. Agrologia. 2(1): doi: 10.30598/a.v2i1.276.

Vivaldy, LA, RM Max. and M Guntur. 2017. Insidensi penyakit virus pada tanaman cabai (Capsicum anuum) di Desa Kakaskasen II Kecamatan Tomohon Utara Kota Tomohon. Cocos. 1(6): 1-9.

Windarningsih, M, MT Fauzi, A Rohyadi, \& I Muthahanas. 2018. Penyebaran penyakit virus daun menguning dan keriting pada cabai rawit di Kabupaten Lombok Utara. Crop Agro. 11: 145-150.

Žanić, K, D Ban, SG Ban, TG Čuljak, \& G Dumičić. 2009. Response of alate aphid species to mulch colour in watermelon. Journal of Food, Agriculture and Environment. 7(3-4): 496502. 